CURRENT

Jurnal Kajian Akuntansi dan Bisnis Terkini

https://current.ejournal.unri.ac.id

hitps:/current.ejournal.untiacid

\title{
STUDI EMPIRIS PENYERAPAN ANGGARAN DAN FAKTOR DETERMINASINYA PADA PEMERINTAH KOTA PEKANBARU
}

\author{
Wanda Hamidah ${ }^{1}$, Yuneita Anisma ${ }^{2}$, Devi Safitri ${ }^{3 *}$ \\ ${ }^{123}$ Program Studi Akuntansi, Fakultas Ekonomi dan Bisnis, Universitas Riau, Pekanbaru \\ *E-mail: devisafitri@lecturer.unri.ac.id
}

\begin{tabular}{l} 
Keywords \\
\hline Budget Planning, \\
Human Resources \\
Competence, \\
Motivation, \\
Organizational \\
Commitment, Budget \\
Absorption \\
\hline Article Information \\
\hline Received: \\
2020-07-23 \\
Accepted: \\
2020-11-20 \\
Available online: \\
2020-11-29
\end{tabular}

\begin{abstract}
The purpose of this research is to find out the influence of budget planning, human resource competence, organizational motivation towards budgets in the regional organizations of the city of Pekanbaru. The research method used is a quantitative re search method with primary data obtained from questionnaire data measured using a Likert scale. The study population was all Regional Organizations in the Government of Pekanbaru. This sample researchers are the chief of regional organizations, Chief of Subdivision and treasurer of expenditure at 43 regional organizations in Pekanbaru City selected using purposive sampling method. Data collection was carried out through a survey using a questionnaire that was distributed to respondents. This research uses multiple linear analysis method with SPSS version 22. The results of this study indicate that budget planning, human resource competencies, motivation, and organizational commitment affect budget absorption in Pekanbaru City Government .
\end{abstract}

\section{PENDAHULUAN}

Tujuan pemerintah yang tercantum di dalam pembukaan Undang-Undang Dasar Negara Republik Indnesia tahun 1945 yaitu untuk melindungi segenap bangsa Indonesia dan seluruh tumpah darah Indonesia, memajukan kesejahteraan umum, mencerdaskan kehidupan bangsa dan ikut melaksanakan ketertiban dunia. Untuk melaksanakan semua itu tentu harus didukung dengan tersedianya dana. Dana yang dibutuhkan tersebut dikelola sebagaimana dimaksud dalam Undang-Undang Dasar Negara Republik Indonesia tahun 1945 tentang Pengelolaan Keuangan Negara perlu dilaksanakan secara profesional, terbuka, dan bertanggungjawab untuk sebesar-besarnya kemakmuran rakyat, hal ini diwujudkan dalam Anggaran Pendapatan dan Belanja Negara (APBN). Sama halnya dengan Negara, setiap daerah di Indonesia juga memiliki wewenang untuk mengelola keuangannya sendiri yang tercantum dalam Anggaran Pendapatan dan Belanja Daerah (APBD). 
Penyerapan anggaran merupakan hal yang sangat penting dalam suatu instansi, dimana fungsinya adalah untuk mengetahui keadaan keuangan suatu instansi. Penyerapan anggaran adalah realisasi dari anggaran, dimana scara umum penyerapan anggaran merupakan pencapaian dari suatu estimasi yang hendak dicapai selama periode waktu tertentu dipandang pada saat tertentu. Penetapan anggaran yang baik diperlukan agar tercapainya prioritas utama yaitu optimalisasi dalam pelayanan publik dimana masih ditemukan keluhan masyarakat mengenai alokasi anggaran yang tidak sesuai dengan kebutuhan dan skala prioritas masyarakat serta berbagai bentuk pengalokasian anggaran yang kurang mencerminkan aspek ekonomis, efisien, dan efektif dalam pengelolan anggaran (Tresnayani dan Gayatri, 2016).

Dalam hal ini pemerintah daerah memiliki peran penting dalam mengoptimalkan penetapan dan pelaksanaan penyerapan anggaran sebagai sumber daya manusia yang akan memberikan manfaat bagi masyarakat. Hal ini terlaksana jika pengelolaan keuangan dilaksanakan secara efektif dan efisien. Namun kenyataanya masih banyak hal-hal yang diharapkan oleh masyarakat terhadap pemerintah untuk peningkatan kesejahteraan tidak dapat terpenuhi. Salah satu faktor penyebabnya adalah rendahnya serapan anggaran daerah. Kegagalan target penyerapan anggaran ini akan mengakibatkan hilangnya manfaat belanja karena dana yang dialokasikan ternyata tidak semuanya dapat dimanfaatkan, yang artinya terjadi iddle money (BPKP, 2011).

Salah satu fenomena rendahnya penyerapan anggaran terjadi di kota Pekanbaru. Beberapa dinas seperti Dinas Pekerjaan Umum dan Penataan Ruang, Dinas Perumahan dan Kawasan Pemukiman, dan Dinas Perhubungan belum melakukan realisasi anggaran sepenuhnya sehingga merugikan masyarakat (riaumandiri.com). Tidak hanya itu, daya serap APBD pada tahun 2018 masih jauh dari harapan. Dimana terdapat catatan realisasi fisik hanya 9\%, sedangkan realisasi keuangan hanya berkisar 7\% dan nilai ini dianggap sangat rendah untuk penyerapan anggaran kota Pekanbaru sebagai ibukota Provinsi Riau, sehingga pelaksanaan kegiatan pada tiap dinas berjalan lambat untuk memberikan pelayanan kepada msyarakat (riaupos.com).

Disisi lain, realisasi keuangan Anggaran Pendapatan Belanja Daerah (APBD) pada Provinsi Riau tahun 2018 mengalami penurunan realisasi dibandingkan tahun 2017. Dimana serapan APBD tahun 2018 masih lebih rendah, untuk realisasi keuangan terdapat selisih berkisar 6.56 persen. Sedangkan pada realisasi fisik selisihnya berkisar 2 persen. Dimana pada tahun 2018 penyerapan anggaran mencapai 81,44 persen atau Rp8,4 triliun dengan realisasi fisik sebesar 91,77 persen. Dari total APBD Rp10,3 triliun, realisasi belanja tidak langsung. 
Berdasarkan penerbitan Surat Perintah Pencairan Dana (SP2D) sampai dengan tanggal 31 Desember 2018 lalu hanya sebesar 50,16 persen atau Rp5,1 triliun, dari target 56,10 persen atau Rp5,7 triliun. Sementara untuk belanja langsung, pemeritah setempat hanya merealisasikan Rp3,2 triliun atau 31,26 persen dari target 43,90 persen (riau.go.id)

Menurut Halim (2014:98) persoalan rendahnya penyerapan anggaran pada pemerintah daerah disebabkan oleh pertama, lemahnya perencanaan anggaran, hal ini dicerminkan oleh pelaksanaan program pemerintah yang lemah dan kurang matang sehingga harus dilakukan revisi-revisi yang nantinya akan menyebabkan kegiatan sulit atau terlambat dieksekusi. Kedua, lamanya proses pembahasan anggaran di DPRD karena banyaknya tarik ulur kepentingan yang efeknya menjadikan kegiatan yang diusulkan menjadi tidak tepat sasaran. Ketiga, lambannya proses tender, tidak sedikit pejabat pembuat komitmen dan kuasa pengguna anggaran yang masih kurang memahami ketentuan pengadaan barang dan jasa serta pelaksanaan anggaran. Keempat, ketakutan menggunakan anggaran, banyaknya kasus yang melibatkan kepala daerah, pengguna anggaran, atau pejabat pembuat komitmen sampai harus berurusan dengan aparat penegak hukum karena ditemukan adanya penyimpangan dalam pelaksanaan kegiatan, sehingga membuat mereka takut dalam mereallisasikan anggaran.

Oleh karena itu, untuk terwujudnya penyerapan anggaran yang baik pada setiap organisasi terkhususnya instansi pemerintah, terdapat beberapa faktor yang dapat mempengaruhi penyerapan anggaran, yaitu: pertama perencanaan anggaran. Dalam siklus pengelolaan keuangan daerah selalu dimulai dari tahapan perencanaan anggaran. Perencanaan merupakan faktor tunggal yang paling penting di tingkat pemerintah daerah, dan dapat memperburuk semua kesulitan lainnya dalam penyerapan anggaran (Zarinah, dkk, 2016). Selain itu perencanaan anggaran yang tidak baik juga sering menimbulkan hambatan dalam pelaksanaannya, sehingga harus dilakukannya revisi atau mungkin tidak dapat direalisasikan sama sekali (Dewi, 2017). Hasil penelitian oleh Iqbal (2018), Zarinah (2015), Ramadhani (2017) menyatakan bahwa perencanaan anggaran berpengaruh pada penyerapan anggaran. Namun hasil penelitian ini berbeda dengan penelitian yang dilakukan oleh Rifai, et al (2016) yang mengatakan bahwa perencanaan tidak berpengaruh terhadap daya serap anggaran.

Kedua, kompetensi sumber daya manusia. Dalam lingkup keuangan daerah, kompetensi sumber daya manusia merupakan salah satu penentu keberhasilan pengelolaan keuangan daerah. Sumber daya manusia juga harus memiliki kompetensi yang baik, dimana kompetensi ini merupakan karakteristik dari seseorang yang mempunyai kemampuan, keterampilan, dan pengetahuan untuk melakukan suatu pekerjaan apabila pemerintah memiliki kompetensi sumber daya manusia yang baik maka proses penyerapan anggaran dalam Satuan Kerja Perangkat Daerah (SKPD) akan terserap 
dengan baik (Saprudin, 2017). Penelitian dahulu juga menyatakan kompetensi sumber daya manusia (SDM) berpengaruh pada penyerapan anggaran dilakukan oleh Sudasri (2016), Iqbal (2018) dan Malahayati (2015). Namun hasil penelitian ini tidak sejalan dengan hasil penelitian yang dilakukan oleh Rifai, et al (2016) yang menyatakan bahwa faktor sumber daya manusia tidak mempunyai pengaruh pada penyerapan anggaran.

Ketiga, Motivasi. Motivasi memiliki hubungan dengan lingkungan kerja sehingga untuk meningkatkan hasil kerja maka motivasi memiliki pengaruh penting terhadap kinerja pegawai karna dengan adanya daya perangsang dari atasan kepada bawahan maka akan membuat pegawai menjadi lebih tersemangati dan menyelesaikan pekerjaan dengan baik. Motivasi terbentuk dari sikap pegawai dalam menghadapi situasi kerja ditempat bekerja. motivasi merupakan kondisi atau energi yang menggerakkan diri/pegawai yang terarah untuk mencapai tujuan organisasi maupun pegawai itu sendiri. Hasil penelitian Laka,et al (2017) menyatakan bahwa terdapat pengaruh positif pada motivasi terhadap penyerapan anggaran belanja modal dan juga oleh penelitian Sanjaya (2018) yang menyatakan hasil penelitian ini menunjukkan bahwa motivasi kerja berpengaruh secara signifikan terhadap kinerja pegawai. Keempat, komitmen organisasi.

Dalam proses penyusunan anggaran juga diperlukan komitmen dari pihak-pihak yang terlibat dalam proses tersebut. Sejauh mana perencanaan dapat terealisasi semua bergantung pada tingkat komitmen organisasi pemerintah selaku pengelola anggaran tersebut. Komitmen tinggi yang dimiliki pegawai terhadap organisasi, membuat pegawai tersebut akan lebih mementingkan kepentingan organisasi dari pada kepentingan pribadinya. Hasil penelitian yang dilakukan Putri (2017) menyatakan bahwa komitmen organisasi berpengaruh positif dan signifikan terhadap penyerapan anggaran. Penelitian yang dilakukan oleh Mastuti dan Iqbal (2017) juga menyatakan Komitmen Manajemen berpengaruh positif dan signifikan terhadap penyerapan anggaran. Dan penelitian Alumbida (2016) juga menjelaskan bahwa secara parsial, komitmen organisasi berpengaruh positif tetapi tidak signifikan terhadap penyerapan anggaran.

Berdasarkan uraian diatas penulis tertarik untuk meneliti kembali terkait penyerapan anggaran. Ketidakkonsistenan hasil penelitian mengenai penyerapan anggaran mengindikasikan bahwa perlunya diteliti kembali. Penelitian ini merupakan pegembangan dari penelitian Sudasri (2016) yang meneliti "Pengaruh Perencanaan Anggaran Dan Kompetensi Sumber Daya Manusia Terhadap Penyerapan Anggaran (Studi Empiris pada SKPD Kota Padang)". Penelitian ini menambakan dua variabel baru yaitu motivasi dan komitmen organisasi yang mana ini merupakan rujukan dari penelitian sebelumnya untuk 
menambahkan variabel lain dalam mengukur penyerapan anggaran. Hal ini dikarenakan variabel motivasi dan komitmen organisasi masih terdapat perbedaan hasil pada penelitian sebelumnya terhadap penyerapan anggaran. Selain itu penelitian ini akan dilakukan pada OPD kota Pekanbaru. Sehingga hal ini menjadi motivasi penulis untuk melakukan penelitian yang bertujuan untuk menguji Pengaruh Perencanaan Anggaran, Kompetensi Sumber Daya Manusia, Motivasi dan Komitmen Organisasi Terhadap Penyerapan Anggaran pada Organisasi Perangkat Daerah Kota Pekanbaru.

\section{PENGEMBANGAN HIPOTESIS}

\section{Pengaruh Perencanaan Anggaran terhadap Penyerapan Anggaran}

Halim (2014: 104) menjelaskan bahwa penyerapan anggaran yang maksimal harus juga diikuti dengan perencanaan anggaran yang baik. Penyerapan anggaran yang maksimal tanpa adanya perencanaan anggaran yang baik dapat dikatakan sebagai suatu hal yang mustahil akan terwujud. Dalam Iqbal (2018) bahwa semakin matang pengelola anggaran dalam merencanakan, maka program kerja/kegiatan dalam satu tahun anggaran akan berjalan dengan baik, sehingga target penyerapan anggaran dapat tercapai tepat pada waktunya. Keterlambatan realisasi anggaran akan berdampak pada tidak berjalannya program kerja pemerintah yang secara tidak langsung tentunya akan memberi dampak buruk terhadap kinerja pemerintah seperti timgkat penyerapan anggaran yang belum maksimal.

Hasil penelitian yang dilakukan oleh Zarinah (2015), Ramadhani (2017) dan Alumbida (2016) mengatakan bahwa perencanan anggaran berpengaruh terhadap tingkat penyerapan anggaran, hal ini menunjukkan bahwa semakin baik perencanaan anggaran maka akan semakin baik tingkat penyerapan anggaran. Berdasarkan penelitian dan landasan teori diatas maka hipotesis yang dapat diajukan adalah:

\section{$\mathrm{H}_{1}$ : Perencanaan anggaran berpengaruh terhadap tingkat penyerapan anggaran.}

\section{Pengaruh Kompetensi Sumber Daya Manusia Terhadap Tingkat Penyerapan Anggaran}

Sumber daya manusia yang berkompetensi tinggi akan menjadi keunggulan tersendiri dalam sebuah organisasi sekaligus sebagai pendukung daya saing organisasi dalam era globalisasi dan menghadapi lingkungan kerja serta kondisi sosial masyarakat yang mengalami perubahan yang dinamis. Kompetensi merupakan kemampuan sumber daya manusia untuk melaksanakan tugas dan tanggungjawab terhadap pekerjaan yang dilandasi pengetahuan, keterampilan dan sikap yang menjadi karakteristik individu yang berpengeruh langsung terhadap atau dapat memprediksi kinerja yang sangat baik Wibowo (2014:271). Pengelolaan keuangan daerah dimulai dengan tahap perencanaan dan diakhiri dengan evaluasi yang 
menghasilkan dokumen anggaran. Kualitas perencanaan hingga menghasilkan hasil akhir yang baik ditentukan oleh kompetensi sumber daya manusia yang terlibat dalam proses perencanaan tersebut agar dapat terjalankan dengan baik. Penelitian yang dilakukan oleh Iqbal (2018), Laka, et al (2017) dan Sudasri (2016) memberikan hasil bahwa kompetensi sumber daya manusia memilki pengaruh positif terhadap penyerapan anggaran, dapat diartikan bahwa semakin tinggi kompetensi sumber daya manusia (SDM) maka tingkat penyerapan anggaran akan semakin meningkat. Berdasarkan penjelasan di atas maka dapat dikembangkan hipotesis penelitian sebagai berikut:

\section{$\mathrm{H}_{2}$ : Kompetensi SDM berpengaruh terhadap tingkat penyerapan anggaran.}

\section{Pengaruh Motivasi Terhadap Penyerapan Anggaran}

Menurut Lubis dan Jaya (2019:112) Motivasi adalah keadaan kejiwaan dan sikap mental manusia yang memberi tenaga, mengarahkan, menyalurkan, mempertahankan, melanjutkan tindakan dan prilaku yang mendorong keinginan individu itu untuk melakukan kegiatan-kegiatan tertentu guna mencapai tujuannya. Dengan adanya motivasi dalam organisasi pemerintahan maka kinerja setiap individu akan lebih semangat dalam melaksanakan tugasnya . Apabila motivasi yang ada didalam organisasi baik maka kinerja yang dihasilkan dari organisasi tersebut juga akan baik. Dan sebaliknya jika didalam suatu organisasi tidak ada motivasi maka kinerja yang dihasilkan juga tidak akan baik. Jadi apabila kinerja dari suatu organisasi tersebut sudah baik tentu diharapkan dapat mengasilkan penyerapan anggaran yang baik pula, sehingga dapat mencapai tujuannya untuk meningkatkan pelayanan publik.

Pelitian yang dilakukan laka, et al (2017), Ramadanil (2013), dan Sanjaya (2018) memberikan hasil bahwa motivasi pejabat pengelola keuangan berpengaruh positif pada penyerapa anggaran belanja modal, hal ini berarti bahwa semakin tinggi motivasi dari pejabat pengelola keuangan maka kinerja penyerapan angggaran belanja modal cendrung meningkat. Berdasarkan penjelasan di atas maka dapat dikembangkan hipotesis penelitian sebagai berikut:

\section{$\mathrm{H}_{3}$ : Motivasi berpengaruh terhadap tingkat penyerapan anggaran.}

\section{Pengaruh Komitmen Organisasi Terhadap Penyerapan Anggaran}

Seseorang yang memiliki komitmen tinggi akan berguna bagi dirinya sendiri dan bagi orang lain. Artinya komitmen merupakan suatu keputusan seseorang dengan dirinya sendiri, apakah ia akan melakukan atau tidak melakukan suatu kegiatan dan seseorang yang telah berkomitmen tentu tidak akan ragu-ragu untuk melakukan sesuatu (Sagala, 2013:23). 
Komitmen organisasi yang tinggi tentu akan meningkatkan kinerja yang tinggi (Dewi, 2017). Hal ini dapat dilihat dalam merencanakan berbagai program dan kegiatan sesuai dengan dokumen perencanaan sehingga target penyerapan anggaran dapat tercapai. Untuk mencapai kesesuaian antara perencanaan dengan realisasi maka dibutuhkan konsistensi dan sinergi dari seluruh pengelola anggaran pemerintah yang disebut komitmen organisasi. Dengan komitmen organisasi yang kuat akan memungkinkan setiap anggota memberdayakan seluruh kemampuan atau sumber daya yang dimilikinya dalam menjalankan tugasnya untuk mencapai tujuan organisasinya. Sebaliknya tanpa komitmen maka pekerjaan-pekerjaan yang dilakukan akan terasa sulit sehingga tujuan yang hendak dicapai akan sulit atau bahhkan tidak dapat terealisasikan sesuai dengan yang diharapkan.

Penelitian Alumbida (2016), Mastuti, et al (2017) dan Aldita (2018) memberikan hasil bahwa komitmen organisasi berpengaruh positif terhadap tingkat penyerapan anggaran. Berdasarkan penjelasan di atas maka dapat dikembangkan hipotesis penelitian sebagai berikut:

\section{$\mathrm{H}_{4}$ Komitmen Organisasi berpengaruh terhadap tingkat penyerapan anggaran.}

Berdasarkan tujuan penelitian, tinjauan pustaka dan hasil penelitian terdahulu serta permasalahan yang telah dikemukakan maka sebagai dasar merumuskan hipotesis, disajikan kerangka pemikiran yang dapat dilihat pada gambar 1 berikut:

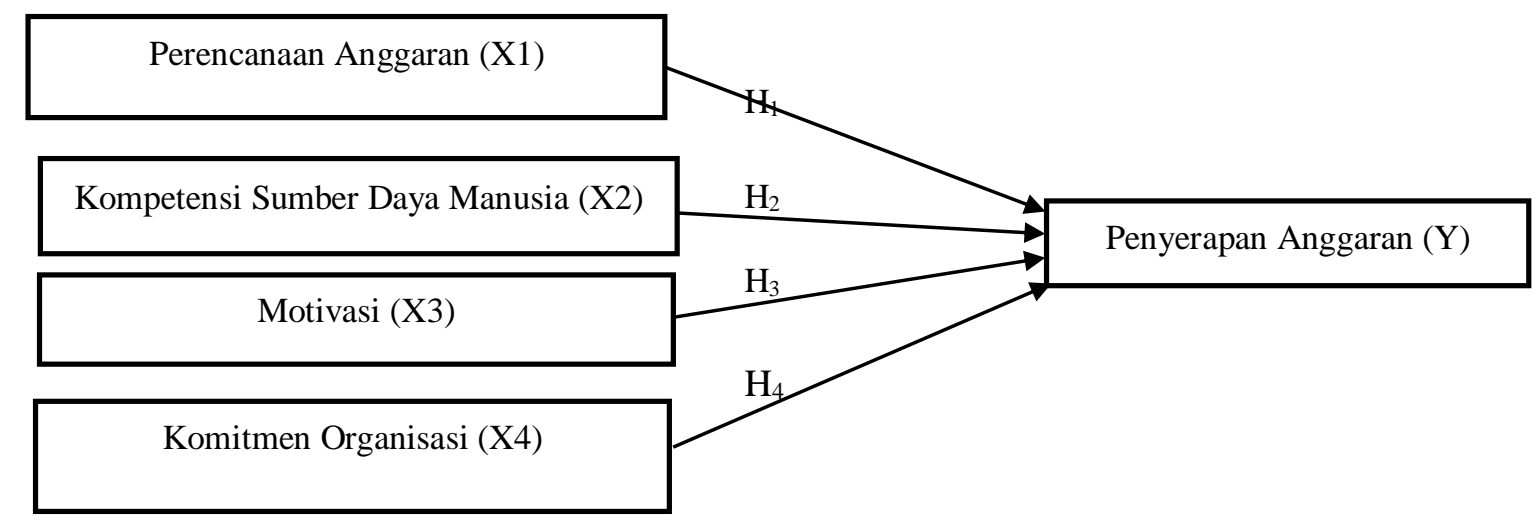

Gambar 1

Kerangka Konseptual

Sumber: Data Olahan (2020)

\section{METODE PENELITIAN}

\section{Lokasi Penelitian}

Lokasi dalam penelitian ini adalah pada Pemerintah Kota Pekanbaru yang merupakan 
ibukota provinsi Riau. Lebih tepatnya penelitin ini dilakukan di Organisasi Perangkat Daerah (OPD) Pemerintah Kota Pekanbaru. Waktu penelitian ini dilakukan pada tahun 2020 hingga selesai.

\section{Populasi dan Sampel}

Populasi yang digunakan seluruh pegawai yang bekerja pada 43 Organisasi Perangkat Daerah (OPD) Pemerintah Kota Pekanbaru. Pengambilan sampel dilakukan menggunakan Purposive Sampling karena peneliti mempunyai tujuan atau target tertentu dalam memilih sampel secara tidak acak (Indriantoro dan Supomo, 2014:131). Sampel yang diambil dalam penelitian ini adalah pegawai pada 43 OPD kota Pekanbaru dimana setiap OPD akan diwakilkan oleh pegawai yang memiliki tugas dan wewenang dalam proses penyusunan dan pertanggungjawaban anggaran. Masing-masing OPD diwakili oleh tiga orang yaitu Kepala Dinas/Camat, Kepala Bagian, dan Bendahara Pengeluaran di masing-masing OPD sehingga jumlah sampel 43 OPD x $3=129$ orang responden.

Pengumpulan data dilakukan dengan teknik survey lapangan yang menggunakan suatu metode pengumpulan data original. Dalam penelitian ini pengumpulan data dengan menyebarkan kuesioner kepada masing masing organisasi perangkat daerah dengan cara mengantar langsung ke setiap OPD Pemerintah Kota Pekanbaru. Pertanyaan berupa suatu daftar pertanyaan yang diberikan kepada responden untuk diisi berdasarkan persepsi masingmasing responden dari satuan kerja (satker) yang menggunakan skala likert dengan skor 1-5.

\section{Definisi Operasional dan Pengukuran Variabel}

Penyerapan anggaran (Y) didefinisikan sebagai proporsi anggaran satuan kerja yang telah dicairkan atau direalisasikan dalam satu tahun anggaran (Noviwijaya, 2013). Variabel ini diukur dengan menggunakan empat indikator yang dijabarkan ke dalam delapan pertanyaan dan diukur dengan skala likert 1-5. Instrumen penelitian yang digunakan berupa kuesioner yang diadopsi dari penelitian Monik Zarinah (2015). Empat indikator tersebut adalah: 1 . Perbandingan realisasi anggaran dengan target penyerapan anggaran, 2. Realisasi pertriwulan, 3. Konsistensi dalam pelaksanaan (program atau kegiatan) dan 4. Ketepatan waktu/jadwal penyerapan setiap bulan.

Perencanaan anggaran (X1) Undang-undang Nomor. 25 tahun 2004 pasal 1 ayat (1) mendefinisikan perencanaan sebagai suatu proses untuk memperhitungkan sumber daya manusia untuk mengetahui tindakan masa depan yang tepat melalui urutan pilihan. Variabel ini diukur dengan menggunakan instrumen yang diadopsi dari penelitian (Zarinah, 2015). Variabel ini diukur dengan skala likert 1-5 dengan enam indikator yang dijabarkan ke dalam 
dua belas pertanyaan. Enam indikator tersebut adalah: 1. Partisipasi , 2. Akurasi Data, 3. Keterlambatan Pengesahan APBD, 4. Pendekatan dan Instrumen dalam Penyusunan Anggaran, 5. Perencanaan dan Kebutuhan dan 6. Revisi atau Perubahan.

Kompetensi Sumber Daya Manusia (X2) adalah kemampuan sumber daya manusia untuk melaksanakan tugas dan tanggung jawab yang diberikan kepadanya dengan bekal pendidikan, pelatihan, dan pengalaman yang memadai (Widodo, 2011:2003). Undang-Undang Nomor 13 Tahun 2003 Tentang Ketenagakerjaan menjelaskan bahwa kompetensi adalah kemampuan individu yang mencakup aspek pengetahuan, sikap dan keterampilan kerja yang sesuai standar yang telah ditetapkan. Variabel ini diukur dengan menggunakan indikator yang diadopsi dari penelitian Iqbal (2018). Variabel ini diukur dengan skala likert 1-5 dengan empat indikator yang dijabarkan kedalam sembilan pertanyaan. Tiga indikator tersebut adalah: 1. Knowledge, 2. Skill, 3. Attitude.

Motivasi (X3) didefinisikan sebagai perubahan dari energi di dalam diri seseorang yang ditandai dengan munculnya feeling dan didahului dengan tanggapan terhadap adanya tujuan (Robbins, 2015:117). Variabel ini diukur dengan menggunakan instrumen yang diadopsi dari penelitian laka, et al (2017). Variabel ini diukur dengan skala likert 1-5 dengan dua indikator yang dijabarkan ke dalam sebelas pertanyaan. Adapun indikatornya adalah faktor individual dan faktor organisasional. Faktor individual adalah kebutuhan-kebutuhan (needs), tujuan-tujuan (goals), sikap (attitudes), dan kemampuan (ability). Sedangkan pembayaran upah/gaji, kemampuan pekerja, hubungan sesama pegawai, pengawasan, pujian, dan pekerjaan itu sendiri tergolong pada faktor organisasional.

Komitmen organisasi (X4) adalah suatu keadaan dimana seorang berniat mememelihara keanggotan dalam suatu organisasi dan memihak pada suatu organisasi tertentu serta dengan tujuan-tujuannya. Variabel ini diukur dengan menggunakan instrument yang diadopsi dari penelitian Iqbal (2018). Variabel ini diukur dengan skala likert 1-5 dengan tiga indikator yang dijabarkan ke dalam enam pertanyaan. Tiga indikator tersebut adalah: 1 . Keinginan yang kuat untuk tetap menjadi anggota organisasi, 2. Kemauan yang besar untuk berusaha bagi organisasi dan 3. Kepercayaan yang kuat dan penerimaan terhadap nilai dan tujuan organisasi.

\section{Teknik Analisis Data}

Analisis data dalam penelitin ini dilakukan dengan menggunaan analisis regresi linear berganda dengan bantuan program SPSS (Statistical Package for Social Science). Beberapa teknik analisis data yang dilakukan dalam penelitian ini yaitu: analisis statistic deskriptif, uji 
kualitas data, uji asumsi klasik, analisis regresi berganda dan uji hipotesis. Persamaan di bawah ini digunakan untuk menguji hipotesis dalam penelitian ini:

$$
Y=a+\beta_{1} X_{1}+\beta_{2} X_{2}+\beta_{3} X_{3}+\beta_{4} X_{4}+e
$$

Dimana:

$\mathrm{Y}$

A

$\beta 1, \beta 2, \beta 3$

$\mathrm{X} 1$

$\mathrm{X} 2$

X3

$\mathrm{X} 4$

$\mathrm{E}$
: Penyerapan Anggaran

: Konstanta

: Koefisien Regresi

: Perencanaan Anggaran

: Kualitas Sumber Daya Manusia

: Motivasi

: Komitmen Organisasi

: Error

\section{HASIL PENELITIAN DAN PEMBAHASAN}

Pengumpulan data pada penelitian dilaksanakan dengan menyebarkan kuesioner di OPD Kota Pekanbaru dengan 43 OPD sebagai sampelnya. Sehingga total penyebaran adalah 129 buah kuesioner. Dari kuesioner yang dibagikan kepada responden, yang diterima kembali berjumlah 105 kuesioner.

\section{Hasil Analisis Statistik Deskriptif}

\section{Tabel 1}

\section{Statistik Deskriptif}

\begin{tabular}{lccccc}
\hline \multicolumn{1}{c}{ Variable } & N & Min & Max & Mean & Std. Dev. \\
\hline Penyerapan Anggaran & 105 & 3 & 5 & 4,261905 & 0,747169 \\
Perencanaan Anggaran & 105 & 3 & 5 & 4,113492 & 0,728829 \\
Kompetensi Sumber Daya & 105 & 3 & 5 & 4,216931 & 0,669025 \\
Manusia & 105 & 3 & 5 & 4,089177 & 0,686472 \\
Motivasi & 105 & 2 & 5 & 4,230952 & 0,750999 \\
Komitmen Organisasi & & & & & \\
\hline
\end{tabular}

Sumber: Data Olahan (2020)

Berdasarkan hasil statistik deskriptif tersebut menunjukkan bahwa nilai rata-rata (mean) lebih besar dibandingkan nilai standar devisiasi pada masing-masing variabel yang mengindikasikan bahwa nilai penyimpangan data kecil, maka nilai (mean) dapat digunakan sebagai representasi dari keseluruhan data. 


\section{Hasil Uji Asumsi Klasik}

Uji normalitas memiliki dua cara pengujian, yaitu dengan analisis grafik (grafik

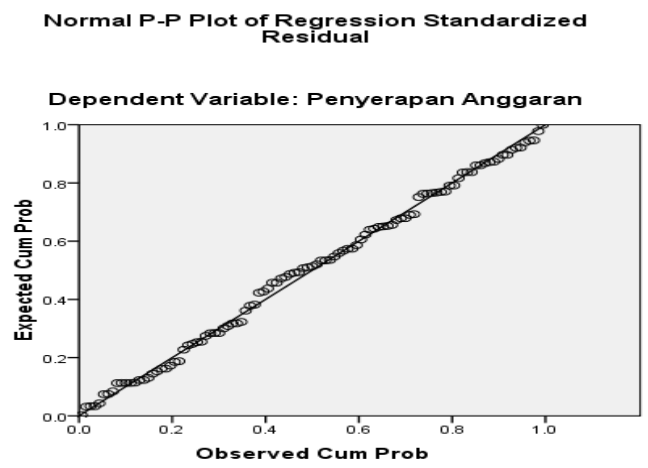

Normal P-Plot dan Histogram) dan statistik dengan One-Sample Kolmogorov-Smirnov Test.

\section{Gambar 2}

\section{Hasil Uji Normalitas dengan Normal P-P Plot}

Sumber: Data Olahan SPSS (2020)

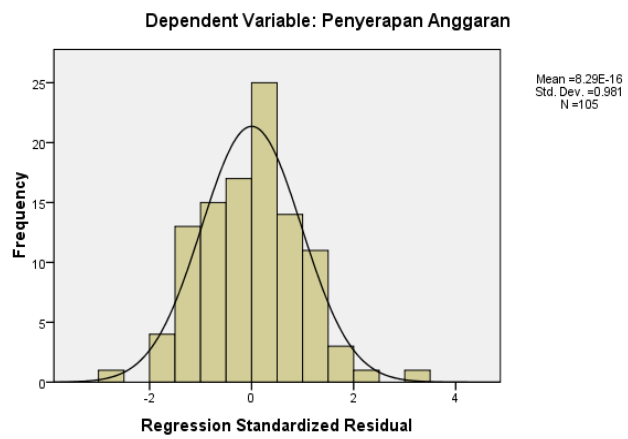

\section{Gambar 3}

Hasil Uji Normalitas dengan Histogram

Sumber: Data Olahan SPSS (2020)

Dari gambar 3 di atas dapat kita lihat bahwa data menyebar di sekitaran garis diagonal dan mengikuti arah diagonal. Dengan demikian dapat disimpulkan bahwa uji normalitas dengan Normal P-plot menunjukkan data terdistribusi normal. Selanjutnya gambar 2 di atas memberikan gambar bahwa grafik histogram membentuk lonceng dan tidak mencong ke kanan atau ke kiri. Dengan demikian dapat disimpulkan bahwa uji normalitas dengan grafik Histogram menunjukkan data berdistribusi normal. 
Tabel 3

Smirnov Test

\begin{tabular}{llr}
\hline $\mathrm{N}$ & & \multicolumn{2}{c}{ Unstandardized Residual } \\
Normal Parameters & Mean & 105 \\
& Std. & .0000000 \\
& Deviation & 200.973 .455 \\
Most Extreme Differences & Absolute & .047 \\
& Positive & .036 \\
Kolmogorov-Smirnov Z & Negative & -.047 \\
Asymp. Sig. (2-tailed) & & .482 \\
a. Test distribution is Normal. & & .974 \\
b. Calculated from data. & & \\
\hline
\end{tabular}

Sumber: Data Olahan SPSS (2020)

Berdasarkan tabel di atas dapat disimpulkan bahwa data pada sampel penelitian ini terdistribusi secara normal atau diambil dari populasi yang normal. Hal ini ditunjukan dari nilai sig > 0,05 yaitu sebesar 0,974.

Uji multikolonieritas bertujuan untuk menguji apakah model regresi ditemukan adanya kolerasi antara variabel bebas (independent).

\section{Tabel 4}

Hasil Uji Multikolonearitas

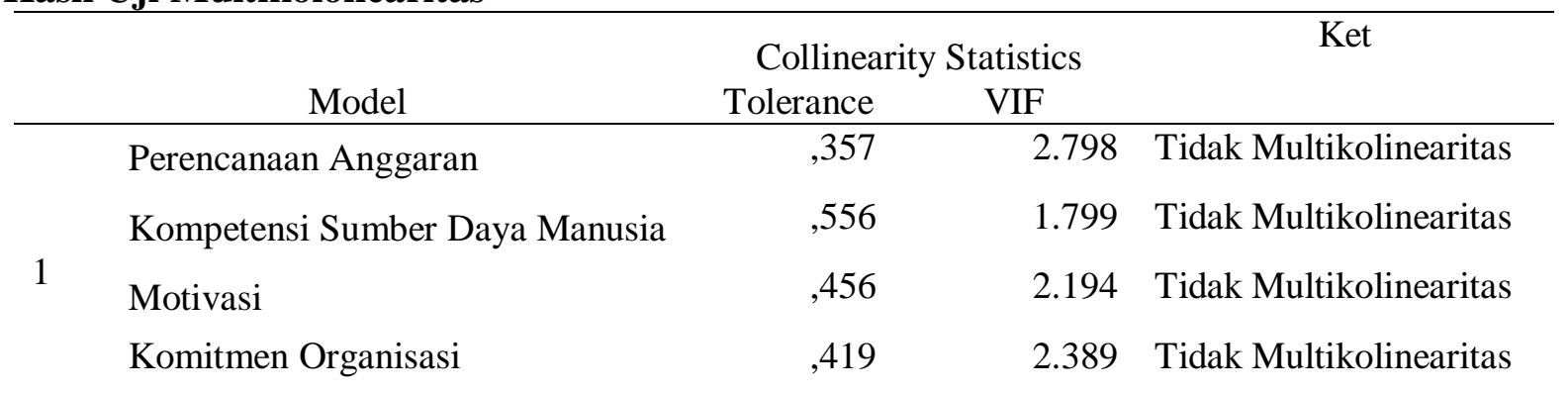

Sumber: Data Olahan SPSS (2020)

Model regresi untuk variabel independen yang diajukan oleh peneliti untuk diteliti bebas dari multikolinearitas. Hal ini dapat dibuktikan dengan melihat tabel diatas yang menunjukkan nilai Tolerance di setiap variabel independen $>0,10$ serta nilai VIF dari masingmasing variabel independen $<10$.

Uji heteroskedastisitas dilakukan untuk melihat apakah didalam model regresi terdapat ketidaksamaan variance dari residual satu pengamatan dengan pengamatan lainnya. cara mendeteksi ada atau tidaknya heteroskedastisitas dengan scatterplot:

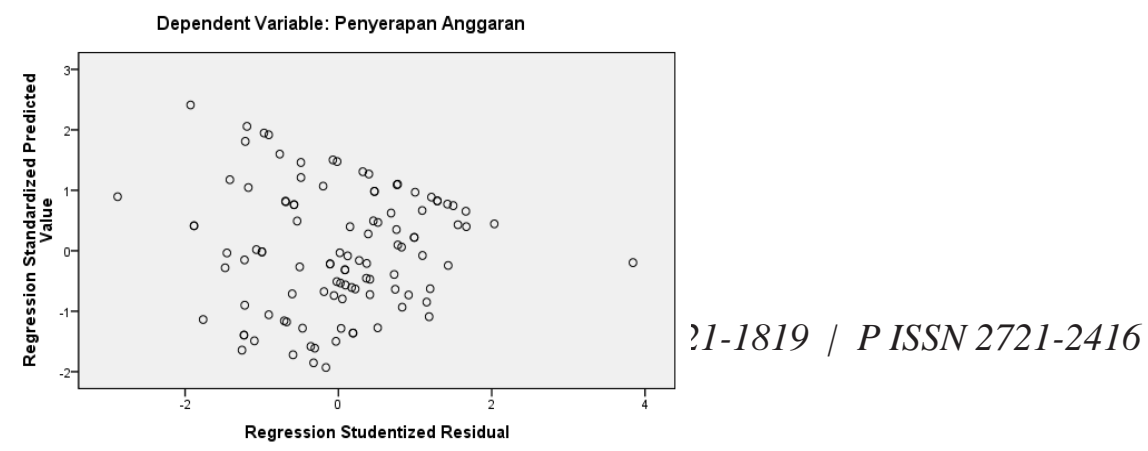




\section{Gambar 4}

Hasil Uji Heteroskedastisitas dengan Scatterplot

Sumber: Data Olahan SPSS (2020)

Berdasarkan grafik bisa dilihat jika titik-titik tersebar secara acak yang tidak membentuk suatu pola dan garis tertentu. Sehingga, dapat dikatakan bahwa model regresi yang terdapat di penelitian ini bebas dari heteroskedastisitas.

\section{Hasil Uji Regresi Linear Berganda}

Hasil uji regresi linier berganda dapat dilihat sebagai berikut:

\section{Tabel 5}

Uji Regresi Linear Berganda

\begin{tabular}{|c|c|c|c|c|c|}
\hline Model & $\begin{array}{l}\text { Unsta } \\
\text { Coe } \\
\text { B }\end{array}$ & $\begin{array}{l}\text { dardized } \\
\text { ficients } \\
\text { Std. Error }\end{array}$ & $\begin{array}{c}\text { Standardized } \\
\text { Coefficients } \\
\text { Beta }\end{array}$ & $\mathbf{T}$ & Sig. \\
\hline (Constant) & -12.621 & 2.404 & & -5.251 & .000 \\
\hline Perencanaan Anggaran & .182 & .064 & .213 & 2.857 & .005 \\
\hline $\begin{array}{l}\text { Kompetensi Sumber } \\
\text { Daya Manusia }\end{array}$ & .245 & .070 & .209 & 3.486 & .001 \\
\hline Motivasi & .476 & .074 & .426 & 6.432 & .000 \\
\hline Komitmen Organisasi & .208 & .075 & .191 & 2.769 & .007 \\
\hline
\end{tabular}

Sumber: Data Olahan SPSS (2020)

Berdasarkan data olahan dengan bantuan program SPSS 22.0 membentuk persamaan regresi linier berganda, sebagai berikut:

$$
Y=-12,621+0,182 X_{1}+0,245 X_{2}+0,476 X_{3}+0,208 X_{4}+e
$$

\section{Hasil Uji Statistik $t$}

Berdasarkan hasil uji statistik $\mathrm{t}$ dapat disimpulkan apabila $\mathrm{t}_{\text {hitung }}<\mathrm{t}_{\text {tabel }}$ maka $\mathrm{H}_{0}$ diterima dan $\mathrm{H}_{\mathrm{a}}$ ditolak (tidak berpengaruh). $\mathrm{T}_{\text {tabel }}$ dilihat dengan derajat bebas $=\mathrm{n}-\mathrm{k}(\mathrm{df}=$ $105-4=101)$, sehingga diperoleh $T_{\text {tabel }}$ pada taraf signifikan 5\% sebesar $(1,98373)$ dan apabila tingkat sig.t $<\alpha 0.05$ maka secara parsial variabel independen dan variabel dependen tersebut tidak ada hubungan yang signifikan.

Apabila $t_{\text {hitung }}>\mathrm{t}_{\text {tabel }}$ maka $\mathrm{H}_{0}$ ditolak dan $\mathrm{Ha}$ diterima (berpengaruh). $\mathrm{T}_{\text {tabel }}$ dilihat dengan derajat bebas $=\mathrm{n}-\mathrm{k}(\mathrm{df}=105-4=101)$, sehingga diperoleh $\mathrm{T}_{\text {tabel }}$ pada taraf signifikan $5 \%$ sebesar $(1,98373)$ dan apabila tingkat sig.t $>\alpha 0.05$ maka secara parsial variabel independen dan variabel dependen tersebut memiliki hubungan yang signifikan. 
Hasil Uji t Coefficients ${ }^{\mathrm{a}}$

\begin{tabular}{llrrrrl}
\hline \multicolumn{1}{c}{ Model } & \multicolumn{1}{c}{ B } & \multicolumn{1}{c}{$\mathbf{t}_{\text {hitung }}$} & \multicolumn{1}{c}{$\mathbf{t}_{\text {tabel }}$} & \multicolumn{1}{c}{ Sig. } & Hasil keputusan \\
\hline \multirow{2}{*}{12.621} & -5.251 & & .000 & \\
& (Constant) & .182 & 2.857 & 1.98373 & .005 & Berpengaruh \\
Perencanaan Anggaran & & & & & \\
Kompetensi Sumber Daya & .245 & 3.486 & 1.98373 & .001 & Berpengaruh \\
& Manusia & .476 & 6.432 & 1.98373 & .000 & Berpengaruh \\
Motivasi & .208 & 2.769 & 1.98373 & .007 & Berpengaruh \\
Komitmen Organisasi & & & & & \\
\hline
\end{tabular}

Sumber: Data Olahan SPSS (2020)

Dari data di atas dapat dilihat variabel perencanaan anggaran, kompetensi SDM, motivasi, komitmen organisasi berpengaruh secara signifikan pada penyerapan anggaran pada OPD Kota Pekanbaru.

\section{PEMBAHASAN}

\section{Pengaruh Perencanaan Anggaran Pada Penyerapan Anggaran}

Hasil penelitian ini memiliki nilai $t_{\text {hitung }}$ sebesar 2,857 dengan nilai signifikan sebesar 0,005 serta $t_{\text {tabel }}$ yang memiliki nilai 1,98373 . Karena nilai $t_{\text {hitung }}>t_{\text {tabel }}(2,2857>1,98373)$ dengan signifikansi $(0,005<0,05)$ menunjukkan $\mathrm{H}_{\mathrm{o} 1}$ ditolak dan $\mathrm{H}_{\mathrm{a} 1}$ diterima. Hal ini menunjukkan variabel perencanaan anggaran memiliki pengaruh secara signifikan pada penyerapan anggaran. Semakin baik perencanaan anggaran yang dilakukan oleh pejabat pengelola keuangan, maka akan meningkatkan penyerapan anggaran. Menurut Nasution (2019:24) di dalam kegiatan pengelolaan keuangan aktivitas perencanaan anggaran bisa digolongkan sebagai suatu tahapan yang sangat penting jika dibandingkan dengan kegiatan yang lainnya. Dimana perencanaan nantinya akan menghasilkan output yang berupa Dokumen Pelaksanaan Anggaran yang akan menjadi dasar dalam pelaksanaan kegiatan pemerintahan dalam satu tahun anggaran, dengan demikian dapat dikatakan bahwa keberhasilan dalam pengelolaan keuangan daerah berawal dari perencanaan. Maka dengan perencanaan anggaran yang baik dapat menghasilkan penyerapan anggaran yang semakin baik.

Hasil penelitian ini didukung oleh penelitian Zarinah (2015), Ramadhani (2017), Alumbida (2016) yang menunjukkan bahwa perencanaan anggaran berpengaruh pada penyerapan anggaran.

\section{Pengaruh Kompetensi Sumber Daya Manusia Pada Penyerapan Anggaran}

Hasil penelitian ini memiliki nilai thitung sebesar 3,486 dengan nilai signifikan sebesar 0,001 serta $t_{\text {tabel }}$ yang memiliki nilai 1,98373. Karena nilai $t_{\text {hitung }}>t_{\text {tabel }}(3,486>1,98373)$ dengan signifikansi $(0,001<0,05)$ dapat disimpulkan bahwa $\mathrm{H}_{\mathrm{ol}}$ ditolak dan $\mathrm{H}_{\mathrm{a} 1}$ diterima. Hal 
ini menunjukkan variabel kompetensi sumber daya manusia memiliki pengaruh secara signifikan pada penyerapan anggaran. Semakin tinggi kompetensi sumber daya manusia maka akan mempengaruhi perilaku pejabat pengelola keuangan dan semakin meningkatkan target penyerapan anggaran. Dalam Undang-Undang Nomor 13 Tahun 2003 Tentang Ketenagakerjaan dikatakan bahwa kompetensi kerja adalah kemampuan individu yang mencakup aspek pengetahuan, keterampilan dan sikap kerja yang sesuai standar yang telah ditetapkan. Organisasi sektor privat atau publik perlu membangun sumber daya manusia yang profesional dan memiliki kompetensi yang tinggi (Halim, 2014:94).

Terkait dengan peran pemerintah dalam mencapai kesejahteraan masyarakat yang optimal dan kebijakan pemerintah harus ditujukan untuk mencapai alokasi sumber daya ekonomi yang efisien, redistribusi pendapatan masyarakat dan stabilitas ekonomi. Oleh sebab itu, pemerintah dituntut memiliki sumber daya manusia yang kompeten dalam mengelola aktivitas pemerintahan seperti menentukan kebijakan dan pengelolaan anggaran. Kompetensi yang dimiliki aparatur pemerintah, baik berupa pengetahuan, keterampilan, maupun sikap perilaku diperlukan dalam menunjang pelaksanaan tugas dalam jabatannya (Iqbal, 2018).

Penelitian ini juga didukung oleh penelitian Iqbal (2018), Laka,et al (2017), Sudasri (2016) yang memberikan hasil bahwa kompetensi sumber daya manusia memiliki pengaruh pada penyerapan anggaran.

\section{Pengaruh Motivasi Terhadap Penyerapan Anggaran}

Hasil penelitian ini memiliki nilai $t_{\text {hitung }}$ sebesar 6,432 dengan nilai signifikan sebesar 0,000 serta $t_{\text {tabel }}$ yang memiliki nilai 1,98373. Dikarenakan nilai $t_{\text {hitung }}>t_{\text {tabel }}(6,432>1,98373)$ dengan signifikansi $(0,000<0,05)$ dapat disimpulkan bahwa $\mathrm{H}_{\mathrm{o} 1}$ ditolak dan $\mathrm{H}_{\mathrm{a} 1}$ diterima. Hal ini menunjukkan variabel motivasi memiliki pengaruh secara signifikan pada penyerapan anggaran. Semakin tinggi motivasi dari pejabat pengelola keuangan maka kinerja penyerapan anggaran cendrung akan meningkat. Menurut Robbins (2015:117) motivasi ialah tanggapan individu, sebagai perubahan yang timbul dan ditandai dengan adanya feeling. Jika seseorang memiliki motivasi, maka orang tersebut akan memiliki alasan untuk mencapai tujuan yang diinginkannya. Dengan adanya motivasi dalam pemerintahan maka kinerja setiap individu akan lebih semangat dalam melaksanakan tugasnya. Jika motivasi kurang dalam organisasi pemerintahan, maka pegawai dan pihak manajerial tidak mempunyai semangat dalam bekerja, mudah menyerah dan kesulitan menyelesaikan tugasnya. 
Hasil penelitian ini juga didukung oleh pelitian yang dilakukan Laka (2017) dan Ramadanil (2013) memberikan hasil bahwa motivasi berpengaruh positif pada penyerapan anggaran belanja.

\section{Pengaruh Hubungan Antara Komitmen Organisasi Terhadap Penyerapan Anggaran}

Hasil penelitian ini memiliki nilai $t_{\text {hitung }}$ sebesar 2,769 dengan nilai signifikan sebesar 0,007 serta $t_{\text {tabel }}$ yang memiliki nilai 1,98373 , karena nilai $t_{\text {hitung }}>t_{\text {tabel }}(2,769>1,98373)$ dengan signifikansi $(0,007<0,05)$ dapat disimpulkan bahwa $\mathrm{H}_{\mathrm{o} 1}$ ditolak dan $\mathrm{H}_{\mathrm{a} 1}$ diterima. Ini membuktikan hubungan variabel komitmen organisasi memiliki pengaruh secara signifikan pada penyerapan anggaran. Semakin tinggi komitmen organisasi maka usaha pejabat pengelola keuangan dalam upaya meningkatkan penyerapan anggaran juga akan mengalami peningkatan. Sopiah (2008:155) menyatakan komitmen organisasi adalah suatu hubungan, yang dilihat dari adanya kemauan untuk mengusahakan tercapainya tujuan organisasi, kepercayaan atas tujuan dan aturan organisasi, dan juga kemauan untuk mempertahankan kedudukan di dalam organisasi. Sedangkan menurut (Lubis dan Jaya, 2019:9) komitmen organisasi adalah individu yang memiliki kelekatan emosi terhadap organisasi yang membuatnya memihak pada organisasi tersebut dan tujuannya, serta berniat memelihara keanggotaannya dalam organisasi tersebut.

Komitmen organisasi dalam penelitian ini merupakan komitmen pimpinan bersama para aparatur selaku manajemen dalam melaksanakan program dan kegiatan yang telah ditetapkan dalam Dokumen Pelaksanaan Anggaran (DPA). Dengan demikian komitmen organisasi dari seluruh Organisasi Perangkat Daerah (OPD) dibutuhkan dalam pelaksanaan penyerapan anggaran daerah secara maksimal. Dengan komitmen yang kuat akan memungkinkan setiap anggotanya untuk memberdayakan seluruh kemampuan yang dimilikinya agar penyerapan anggaran bisa terserap maksimal, sebaliknya kurangnya komitmen organisasi akan membuat pekerjaan yang dilakukan terasa sulit dan bahkan tidak dapat diselesaikan.

Hasil penelitian ini juga didukung oleh penelitian Mastuti, et al (2017), Aldita (2018), Alumbida (2016) yang juga memberikan hasil bahwa komitmen organisasi berpengaruh terhadap penyerapan anggaran.

\section{SIMPULAN}

Menurut hasil penelitian maka penulis menyimpulkan, bahwa perencanaan anggaran memiliki pengaruh signifikan pada penyerapan anggaran. Kompetensi sumber daya manusia memiliki pengaruh pada penyerapan anggaran. Motivasi memiliki pengaruh pada penyerapan 
anggaran. Komitmen organisasi memiliki pengaruh pada penyerapan anggaran.

Selain itu Penelitian ini memiliki beberapa keterbatasan yaitu penelitian ini hanya menggunakan data kuesioner dalam pengambilan analisis data. Penelitian ini hanya dilakukan pada OPD Kota Pekanbaru dan menggunakan variabel perencanaan anggaran, kompetensi sumber daya manusia, motivasi dan komitmen organisasi sebagai variabel independen. Diduga masih banyak faktor lain yang dapat menjadi variabel lain.

Dari penjelasan diatas dapat diberikan saran dalam penelitian berikutnya perlu dilakukan wawancara agar mempermudah bertemu responden dan mempercepat mendapatkan jawaban responden. Hasil penelitian ini memberikan implikasi praktis di sektor pemerintahan mengenai penyerapan anggaran. Diharapkan pada pihak pemerintah, khususnya OPD Kota Pekanbaru untuk senantiasa memaksimalkan perencanaan anggaran yang dilakukan serta berupaya meningkatkan kompetensi dan motivasi para pengelola anggaran dengan mengacu pada prinsip-prinsip anggaran sektor publik, sehingga penyerapan anggaran akan terus mengalami peningkatan. Selanjutnya, menumbuhkan komitmen bagi pengelola anggaran terhadap tujuan-tujuan organisasi agar sesuai dengan karakteristik anggaran sektor publik yang menuntut adanya komitmen dalam mengelola keuangan publik.

Bagi peneliti selanjutnya juga diharapkan dapat melakukan pengujian dengan menambahkan variabel lainnya sehingga mampu mengungkapkan variabel lain yang dapat mempengaruhi penyerapan anggaran pada OPD Kota Pekanbaru. Penelitian selanjutnya diharapkan sampel dan lokasi yang berbeda agar penelitian dapat dibandingkan dengan penelitian sebelumya. Selain itu peneliti selanjutnya diharapkan menggunakan sampel yang lebih besar sehingga dapat memberikan hasil dan gambaran penelitian yang lebih baik dan dapat digeneralisasi.

\section{REFERENSI}

Aldita, A. F. \& Muniruddin, S. (2018). Pengaruh Perencanaan Anggaran, Kualitas SDM, Pemahaman Atas Sistem Akuntansi, Lingkungan Birokrasi dan Komitmen Organisasi Terhadap Tingkat Penyerapan Anggaran SKPD Kota Langsa. Jurnal Ilmiah Mahasiswa Ekonomi Akuntansi (JIMEKA), 3(1), 82-95.

Alumbida, D. I. (2016). Faktor- Faktor yang Mempengaruhi Penyerapan Anggaran Belanja Daerah Pada Pemerintah Kabupaten Kepulauan Talaud. Jurnal Administrasi Publik, 5(2), 141-151.

Badan Pengawas Keuangan Pemerintah. (2011). Menyoal Penyerapan Anggaran. Paris Review Tahun III No. 6.

Dewi, N. L. P. L, Dwiranda A. A. N. B., \& Wirakusuma, M. G. (2017). Pengaruh Perencanaan Anggaran dan Kompetensi SDM Pada Penyerapan Anggaran Pemerintah 
Kabupaten Tabunan dengan Kemampuan Komitmen Organisasi Sebagai Pemoderasi. E-Jurnal Ekonomi dan Bisnis Universitas Udyana. 6(4), 1609-1638.

Halim, A. (2014). "Manajemen Keuangan Sektor Publik Problematika Penerimaan dan Pengeluaran Pemerintah". Salemba Empat: Jakarta.

Iqbal, M. (2018). Faktor-Faktor yang Mempengaruhi Penyerapan Anggaran dengan Komitmen Organisasi Sebagai Pemoderasi. Tesis. Universitas Hasanuddin Makasar.

Laka, E. I., Made, I., Made G. S., \& Dewa G. W. (2017). Faktor-Faktor yang Mempengaruhi Penyerapan Anggaran Belanja Modal dengan Komitmen Orgaisasi Pejabat Pengelola Keuangan Sebagai Variabel Pemodersi. E-Jurnal Ekonomi dan Bisnis Universitas Udayana, 6 (12).

Lubis, J., \& Jaya, I. (2019). Komitmen Membangun Pendidikan. Medan: CV Widya Puspita.

Malahayati, C. (2015). Pengaruh Kapasitas SDM, Perencanaan Anggaran \& Pelaksanaan Anggaran terhadap Serapan Anggaran pada Pemkot Banda Aceh. Tesis. Universitas Syiah Kuala Banda Aceh.

Noviwijaya, A. \& Abdul R. (2013). Faktor-Faktor yang Mempengaruhi Penyerapan Anggaran Satuan Kerja (Studi Empiris Pada Satuan Kerja Lingkup Pembayaran KPPN Semarang I). E-jurnal UNDIP. 2(3), 2337-3806.

Ramadhanil, R. (2013). Pengaruh Partisipasi Penyusunan Anggaran dan Motivasi Kerja Terhadap Kinerja SKPD (Studi Empiris pada SKPD Kab. Tanah Datar). Jurnal Universitas Negri Padang. 1(3).

Rifai, A., Inapty, B. A., \& Sri, P. M. (2016). Analisis yang Mempengaruhi Keterlambatan Daya Serap Anggaran. Jurnal Ilmiah Akuntansi dan Bisnis. 11(1).

Sanjaya, P. (2018). Pengaruh Motivasi Kerja terhadap Kinerja Pegawai Dalam Perspektif Ekonomi Islam. Skripsi. Universitas Islam Negri Raden Intan Lampung.

Saprudin. (2017). Dokumen Perencanaan dan Kompetensi Sumber Daya Manusia Pengaruhnya Terhadap Penyerapan Anggaran. Gorontalo Accounting Jurnal, 1(2), 2614-2074.

Sopiah. (2008). Prilaku Organisasi. Yogyakarta: Andi Offset.

Sudasri, D. (2016). Faktor-Faktor yang Mempengaruhi Penyerapan Anggaran. Jurnal Ekonomi Universitas Negri Padang.

Tresnayani, L. G. A., \& Gayatri. (2016). Pengaruh Asimetri Informasi, Kapasitas Individu dan Kejelasan Sasaran Anggaran Terhadap Terhadap Potensi Terjadinya Budgetary Slack. E-Jurnal Akuntansi Universitas Udayana, 16(2).

Wibowo. (2014). Manajemen Kinerja. Jakarta: Rajagrafindo Persada.

Widodo, J. (2011). Analisis Kebijakan Publik. Malang: Penerbit Bayumedia.

Zarinah, M., Darwanis \& Syukri, A. (2016). Pengaruh Kualitas Sumber Daya Manusia dan 
Perencanaan Terhadap Tingkat Penyerapan Anggaran Satuan Kerja Perangkat Daerah di Kabupaten Aceh Utara. Jurnal Magister Akuntansi Pascasarjana Universitas Syiah Kuala, 5(1), 90-97.

Peraturan Pemerintah Nomor 71 Tahun 2010 Tentang Akuntansi Pemerintahan

PMK No.158/PMK.02/2014 Tentang Aturan Pengenaan Sanksi dan Reward Atas Pelaksanaan Belanka K/L

UU Republik Indonesia No 9 Th 2015 Tentang Pemerintah Daerah

UU Republik Indonesia No 13 Th 2003 Tentang Ketenagakerjaan

UU Republik Indonesia No 25 Th 2004 Tentang Sistem Perencanaan Pembangunan Nasional

Riau.go.id, (2018). Realisasi APBD Riau 2018 Tak Capai Target. https://www.riau.go .id/home/content/2019/01/08/7681-realisasi-apbd-riau-2018-tak-capai-target.

Riaumandiri.co. (2017). OPD Dinilai Tak Mampu Maksimalkan Penyerapan Anggaran, https://www.riaumandiri.id/read/detail/51912/opd-dinilai-tak-mampu-maksimalka npenyerapananggaran .html.

Riaupos.co (2018) Berita Gerak OPD Lambat Realisasi APBD Rendah. https://m.riaupos.co/181870-berita-gerak-opd-lambat-realisasi-apbd -rendah.html, diakses pada 21 Oktober 2019.

Seputarriau.co (2019). Rendahnya serapan anggaran 2018 Dewan Minta OPD Kerja Lebih Efektif.https://www.seputarriau.co/news/detail/6351/rendahnya-serapan-anggaran2018-dewan-minta-opd-kerja-lebih-efektif. 